\title{
The paper punched disc technique for lead in blood samples with abnormal haemoglobin values
}

\author{
G. F. CARTER
}

From the Regional Toxicology Laboratory, Dudley Road Hospital, Birmingham B18 $7 Q H$

ABSTRACT A series of 15 blood samples with haemoglobin levels ranging from $4 \cdot 6-16 \cdot 1 \mathrm{~g} / \mathrm{dl}$ were spotted on to Whatman No. 4 filter paper. Blood samples with low haemoglobin concentrations spread over a greater area of the filter paper than did those with high haemoglobin concentrations. This was further investigated by studying the performance of laboratory-prepared samples, and any effect on the estimation of blood lead value. Blood lead values assayed by the punched disc method on blood samples with low haemoglobin values were unreliable unless the estimated value was adjusted with respect to the area over which the blood had spread.

The method of dropping blood on to filter paper and allowing this to spread and dry before punching out discs of uniform size has been recommended as an alternative to volumetric measurements of blood (Cernik and Sayers, 1971, 1973; Fox and Sayers, 1973; Cernik, 1973a, 1973b, 1974). Although the effect of environmental features such as humidity while spotting the blood, and temperature of drying the filter paper, have been closely examined (Cernik and Sayers, 1971), very little investigation seems to have been carried out on the effect of anaemia upon the size of spot produced.

Cernik (1973b) refers to an 'admittedly few' bloods with haemoglobin values between 9 and $11 \mathrm{~g} / \mathrm{dl}$ giving no significant difference in blood lead values estimated by both the punched disc technique and cathode ray polarography.

During the four years that the punched disc method of blood sampling was used in this laboratory it was noted that blood samples of low haemoglobin concentration spread over a larger area than did blood samples with a normal haemoglobin concentration. This was investigated in two ways. First, 15 blood samples covering as wide a range of haemoglobin values as possible, all of which had been collected and routinely examined on the same day, were spotted on to filter paper and the area of spread measured. Second, various dilutions of a red cell concentrate with plasma were prepared. These dilutions were then examined for haemoglobin concentration, packed cell volume (PCV), red cell count (RBC) and lead concentration. Two spare filter

Received for publication 27 June 1977

Accepted for publication 7 November 1977 paper discs were prepared for each sample so that the area of spread could be determined.

After the second series of samples had been prepared and examined it was decided to prepare a further series of dilutions of red cells in plasma, all of which would have the same lead content. These were examined in the same way as the previously prepared samples.

After using $100 \mu \mathrm{l}$ of blood for spotting on to filter paper it was brought to the author's attention that this contravened recommendations made by Ainsworth et al. (1953) who stated that restricted volumes only, 20-60 $\mu 1$, gave uniformity of spread.

In order to validate the use of $100 \mu$ l samples, two blood samples with haemoglobin values of 4.5 and $16.5 \mathrm{~g} / \mathrm{dl}$ were examined for areas of spread, using both $50 \mu \mathrm{l}$ and $100 \mu \mathrm{l}$ sample sizes.

\section{Materials and methods}

The Haematology Department of Dudley Road Hospital supplied the first 15 samples which had been assayed for haemoglobin and PCV. For the preparation of the other two sets of samples $500 \mathrm{ml}$ of blood was collected into EDTA (dipotassium salt) and partially separated into plasma and a cell concentrate by centrifugation. To the cell concentrate was added $200 \mu \mathrm{l}$ of a solution containing $200 \mu \mathrm{g}$ of lead (as lead chloride). This was then mixed for four hours using a magnetic stirrer. It was estimated that this procedure would raise the lead content of the cell concentrate to approximately $100 \mu \mathrm{g} / \mathrm{dl}$. This was then combined with the separated plasma as shown in Table 1.

For the second series of laboratory-prepared 
Table 1 Details of preparation of laboratory samples

\begin{tabular}{|c|c|c|c|c|c|c|c|c|c|c|c|}
\hline \multirow[t]{2}{*}{ Composition } & \multicolumn{11}{|c|}{ Sample code } \\
\hline & $\begin{array}{l}B O \\
A O\end{array}$ & $\begin{array}{l}B 1 \\
A 1\end{array}$ & $\begin{array}{l}B 2 \\
A 2\end{array}$ & $\begin{array}{l}B 3 \\
A 3\end{array}$ & $\begin{array}{l}B 4 \\
A 4\end{array}$ & $\begin{array}{l}B 5 \\
A 5\end{array}$ & $\begin{array}{l}B 5 \\
A 6\end{array}$ & $\begin{array}{l}B 7 \\
A 7\end{array}$ & $\begin{array}{l}B 8 \\
A 8\end{array}$ & $\begin{array}{l}B 9 \\
A 9\end{array}$ & $\begin{array}{l}B 10 \\
A 10\end{array}$ \\
\hline $\begin{array}{l}\text { Cell concentrate }(\mathrm{ml}) \\
{ }^{*} \text { Plasma }(\mathrm{ml})\end{array}$ & $\begin{array}{r}0 \\
10\end{array}$ & $\begin{array}{l}1 \\
9\end{array}$ & $\begin{array}{l}2 \\
8\end{array}$ & $\begin{array}{l}3 \\
7\end{array}$ & $\begin{array}{l}4 \\
6\end{array}$ & $\begin{array}{l}5 \\
5\end{array}$ & $\begin{array}{l}6 \\
4\end{array}$ & $\begin{array}{l}7 \\
3\end{array}$ & $\begin{array}{l}8 \\
2\end{array}$ & $\begin{array}{l}9 \\
1\end{array}$ & $\begin{array}{r}10 \\
0\end{array}$ \\
\hline
\end{tabular}

*For second set of dilutions spiked plasma was used (see text).

samples, sufficient lead chloride was added to the separated plasma to raise the lead level to equal that of the cell concentrate. This was achieved by dropwise addition of lead chloride solution to the plasma until the peak height of assay was equal to that of the red cell concentrate. Dilutions of the cell concentrate were then prepared as for the first set.

In order to verify that there were no significant differences in matrix effects between the cell concentrate and its plasma, known quantities of lead chloride solution were added in increasing concentration to both the cell concentrate and to its plasma. The calibration curves obtained were identical and therefore it was assumed that the matrix effects were not significantly different.

Blood lead levels were measured by the Delves cup technique (Delves, 1970) with three modifications: hydrogen peroxide was not used for preliminary oxidation of the sample, because this was not necessary when background correction was used; measurements were made at a wavelength of $217.0 \mathrm{~nm}$; and the samples were dried at $150^{\circ} \mathrm{C}$ for 30 seconds on a Gallenkamp hotplate.

For the assay of lead by the punched disc technique, blood samples were spotted as follows: 100 $\mu 1$ of blood was dropped from an Oxford pipette on to a Whatman No. 4 filter paper $(7 \mathrm{~cm}$ diameter) from a height of $1 \mathrm{~cm}$. The papers were then placed into plastic disposable Petri dishes and allowed to dry overnight. A $6 \mathrm{~mm}$ disc was punched from the centre of each blood spot and inserted into a nickel cup for analysis.

For the experiment to validate the usage of $100 \mu l$ of blood for spotting on to filter paper, the above procedure was followed using both $50 \mu 1$ and $100 \mu 1$ of samples with haemoglobin values of 4.5 and $16.5 \mathrm{~g} / \mathrm{dl}$. This was performed in quadruplicate.

When measuring blood lead, a set of standards was estimated by both the volumetric and the punched disc filter paper techniques to check that linearity applied for all relevant levels of lead. These standards covered the range $20-120 \mu \mathrm{g} / \mathrm{dl}$.

All blood lead measurements were carried out in duplicate. Actual lead concentrations of the prepared samples were not estimated; instead, for each set the cell concentrates were designated as having a value of 100 and the concentrations in the other samples were calculated from this.

The area of spread was measured by inserting a sheet of carbon copy paper between the filter paper on to which the blood had been spotted, and a piece

Table 2 Results from random samples

\begin{tabular}{lll}
\hline Haemoglobin $(\mathrm{g} / \mathrm{dl})$ & $P C V(\%)$ & ${ }^{*}$ Area $\left(\mathrm{mm}^{2}\right)$ \\
\hline 16.1 & 44 & 400 \\
15.7 & 47 & 354 \\
15.6 & 43 & 470 \\
15.4 & 44 & 373 \\
13.4 & 36 & 516 \\
13.2 & 38 & 547 \\
12.4 & 37 & 593 \\
12.2 & 38 & 612 \\
11.9 & 37 & 621 \\
11.6 & 33 & 768 \\
10.7 & 30 & 828 \\
9.8 & 31 & 826 \\
8.1 & 25 & 860 \\
6.3 & 21 & 916 \\
4.6 & 14 & 963 \\
\hline
\end{tabular}

*Area = average of two results.

Table 3 Results from first series of laboratory-prepared samples

\begin{tabular}{|c|c|c|c|c|c|c|}
\hline Sample no. & $H b(g / d l)$ & $P C V(\%)$ & $\begin{array}{l}\text { Area of } \\
\text { spread }\left(\mathrm{mm}^{2}\right)\end{array}$ & $\begin{array}{l}\text { *Lead by } \\
\text { volumetric assay }\end{array}$ & $\begin{array}{l}\text { *ead by punched } \\
\text { disc technique }\end{array}$ & Expected result \\
\hline $\begin{array}{l}\text { A10 } \\
\text { A9 } \\
\text { A8 } \\
\text { A7 } \\
\text { A6 } \\
\text { A5 } \\
\text { A4 } \\
\text { A3 } \\
\text { A2 } \\
\text { A1 } \\
\text { A0 }\end{array}$ & $\begin{array}{r}18.4 \\
16.1 \\
14.9 \\
12.7 \\
11.0 \\
9.2 \\
7.2 \\
5.3 \\
3.8 \\
1.9 \\
0.1\end{array}$ & \begin{tabular}{r|}
$54 \cdot 4$ \\
$48 \cdot 7$ \\
$45 \cdot 5$ \\
$38 \cdot 4$ \\
333 \\
$28 \cdot 3$ \\
$21 \cdot 8$ \\
$16 \cdot 7$ \\
$11 \cdot 8$ \\
$6 \cdot 1$ \\
$1 \cdot 3$
\end{tabular} & $\begin{array}{r}266 \\
336 \\
392 \\
578 \\
748 \\
809 \\
849 \\
928 \\
920 \\
1021 \\
1030\end{array}$ & $\begin{array}{r}100 \\
87 \\
77 \\
68 \\
57 \\
50 \\
39 \\
31 \\
21 \\
13 \\
3\end{array}$ & $\begin{array}{r}100 \\
81 \\
40 \\
32 \\
26 \\
18 \\
13 \\
8 \\
8 \\
4 \\
2\end{array}$ & $\begin{array}{r}100 \\
90 \\
80 \\
70 \\
60 \\
50 \\
40 \\
30 \\
20 \\
10 \\
0\end{array}$ \\
\hline
\end{tabular}

* Arbitrary units. 
Table 4 Resuits from second series of laboratory-prepared samples

\begin{tabular}{|c|c|c|c|c|c|c|c|}
\hline Sample no. & $H b(g / d l)$ & $P C V(\%)$ & Area $(\bar{x}$ of 3$)$ & $\begin{array}{l}\text { * Lead by } \\
\text { volumetric assay }(A)\end{array}$ & $\begin{array}{l}\text { *Lead by punched } \\
\text { disc technique }(B)\end{array}$ & $A-B$ & Expected result \\
\hline $\begin{array}{l}\text { B10 } \\
\text { B9 } \\
\text { B8 } \\
\text { B7 } \\
\text { B6 } \\
\text { B5 } \\
\text { B4 } \\
\text { B3 } \\
\text { B2 } \\
\text { B1 } \\
\text { B0 }\end{array}$ & $\begin{array}{r}18.9 \\
17 \cdot 1 \\
15.0 \\
13.0 \\
11.5 \\
9.5 \\
7.9 \\
59 \\
4.0 \\
2.2 \\
0.4\end{array}$ & $\begin{array}{r}53 \cdot 8 \\
49 \cdot 3 \\
43 \cdot 4 \\
37.5 \\
33 \cdot 0 \\
28 \cdot 1 \\
22 \cdot 5 \\
17 \cdot 4 \\
11 \cdot 6 \\
6 \cdot 4 \\
1 \cdot 6\end{array}$ & $\begin{array}{r}365 \\
430 \\
481 \\
654 \\
730 \\
761 \\
853 \\
913 \\
982 \\
1017 \\
1064\end{array}$ & $\begin{array}{r}100 \\
99 \\
98 \\
97 \\
97 \\
98 \\
96 \\
99 \\
98 \\
99 \\
98\end{array}$ & $\begin{array}{r}100 \\
82 \\
72 \\
69 \\
56 \\
48 \\
40 \\
39 \\
36 \\
35 \\
33\end{array}$ & $\begin{array}{r}0 \\
17 \\
26 \\
28 \\
41 \\
50 \\
56 \\
60 \\
62 \\
64 \\
65\end{array}$ & $\begin{array}{l}100 \\
100 \\
100 \\
100 \\
100 \\
100 \\
100 \\
100 \\
100 \\
100 \\
100\end{array}$ \\
\hline
\end{tabular}

*Arbitrary units.

Table 5 Preparation of blood spots using two volumes of bloods with different haemoglobin concentrations

\begin{tabular}{|c|c|c|c|c|}
\hline \multirow{3}{*}{$\begin{array}{l}\text { Volume of blood sample } \\
(\mu l) \\
50\end{array}$} & \multicolumn{4}{|c|}{ Area of spot $\left(\mathrm{mm}^{2}\right)$ for blood with $\mathrm{Hb}$ values of: } \\
\hline & \multicolumn{2}{|l|}{$4.5 \mathrm{~g} / \mathrm{dl}$} & \multicolumn{2}{|l|}{$15 \cdot 5 \mathrm{~g} / \mathrm{dl}$} \\
\hline & $\left.\begin{array}{l}504 \\
493 \\
475 \\
501\end{array}\right\}+\mathrm{CD}$ & $\begin{array}{l}=\quad 493 \\
= \pm \quad 13.0 \\
=\quad 2.6\end{array}$ & $\left.\begin{array}{l}176 \\
167 \\
181 \\
212\end{array}\right\} \mathrm{CD}$ & $\begin{array}{l}=\quad 184 \\
= \pm \quad 19 \cdot 5 \\
=\quad 10.6\end{array}$ \\
\hline 100 & $\left.\begin{array}{r}991 \\
986 \\
987 \\
1009\end{array}\right\} \begin{array}{l}\text { mean } \\
\text { SD } \\
\mathrm{CV}\end{array}$ & $\begin{array}{l}=\quad 993 \\
= \pm \quad 10 \cdot 7 \\
=\quad 1.1\end{array}$ & $\left.\begin{array}{l}426 \\
476 \\
414 \\
418\end{array}\right\} \mathrm{CD}$ & 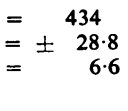 \\
\hline
\end{tabular}

* Standard deviation.

†Coefficient of variation.

of millimetre-squared graph paper. The perimeter of the blood-stained portion was traced and the area enclosed was estimated.

\section{INSTRUMENTS}

All blood lead measurements were made using an Instrumentation Laboratory Model 353 Atomic Absorption Spectrophotometer fitted with an IL Microsampler.

The haematological estimations were carried out on a Coulter Model S.

Nickel cups were obtained from Electronic Developments Ltd, Two Stacks, Priors Wood, Guildford.

\section{Results}

Table 2 shows the haemoglobin concentrations, PCVs and areas of spread of the blood samples supplied by the Haematology Department. Tables 3 and 4 show results of blood lead estimations in which unspiked and spiked plasma respectively were used for dilution. The results of the experiment to validate the use of $100 \mu \mathrm{l}$ blood spots are shown in Table 5 .

Figure 1 shows the area of spread plotted against haemoglobin and PCV values, and Figure 2 shows the discrepancy between the results of blood lead estimations using a volumetric technique and those obtained by the punched disc technique, according to the concentration of haemoglobin in the blood sample. Examples of the size of spot produced are shown in Figures 3-6.

\section{Discussion}

The method of spotting blood on to filter paper has been used as a convenient means of surveying industrial and other populations. In making such preparations it is clearly important to make the collection under the most stringently hygienic conditions. These conditions have been exhaustively discussed by many authors since Cernik and Sayers stated them clearly in 1971.

The CEMA's Note of Guidance (1972) gives information concerning the interpretation of lead levels, haemoglobin levels and a correction nomogram for the lead/PCV relationship. During population studies in this laboratory it was noted that, for a constant dropping height of blood on to filter paper, different areas of spread of blood spot were obtained. Knowing that haemoglobin content may vary, particularly in women and children of various ages, 

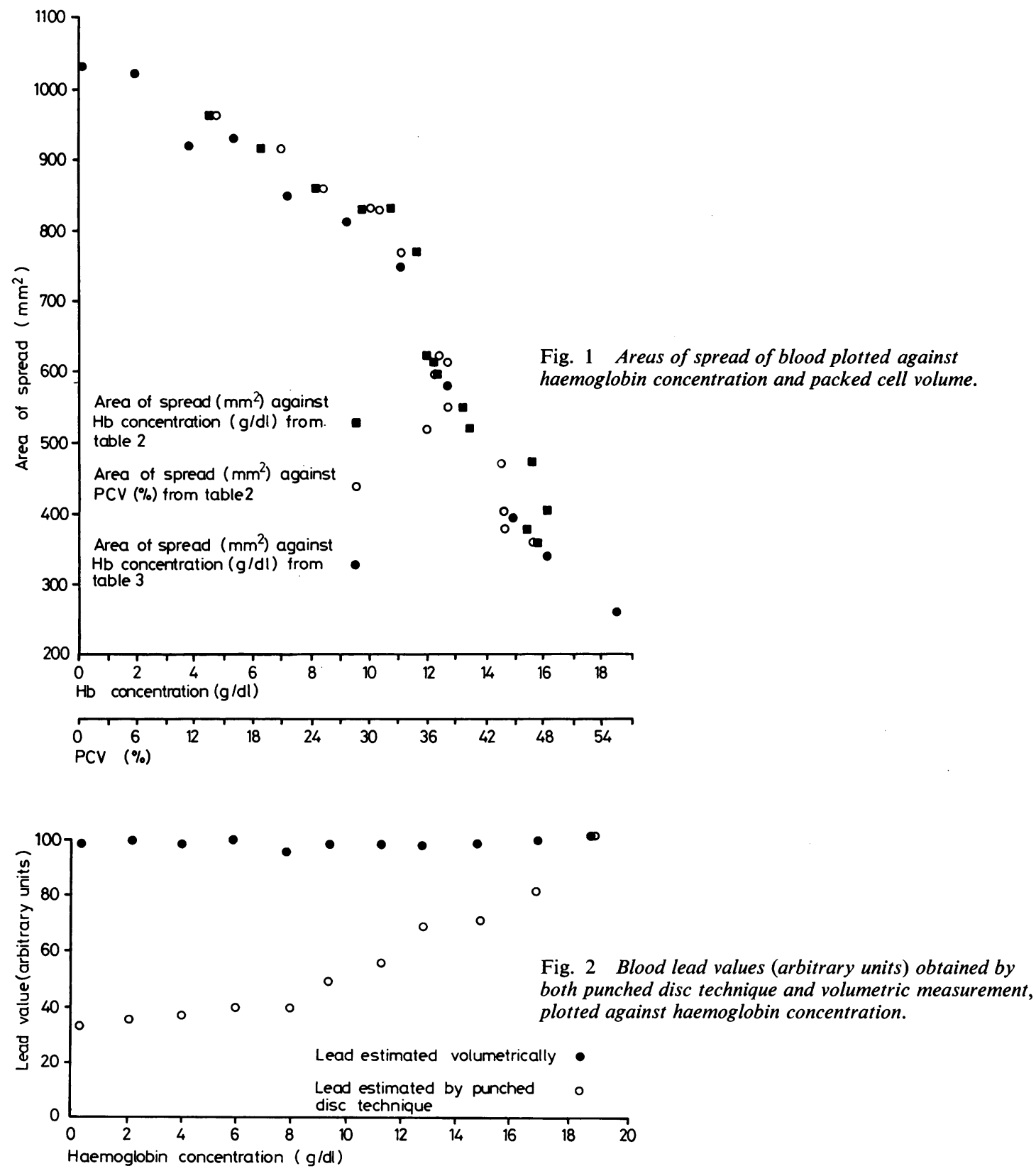

we thought it advisable to investigate this further.

The use of $100 \mu l$ samples is justified by the results obtained in comparing areas of spots produced by using both 50 and $100 \mu l$ quantities of blood.

The results of this investigation show (Table 2) that, in a series of random samples from the Haema- tology Department at this hospital, the area of spot varied both with haemoglobin concentration and PCV.

Unfortunately, after having estimated the area of spread of these samples the filter papers were considered to have been contaminated to such an extent 

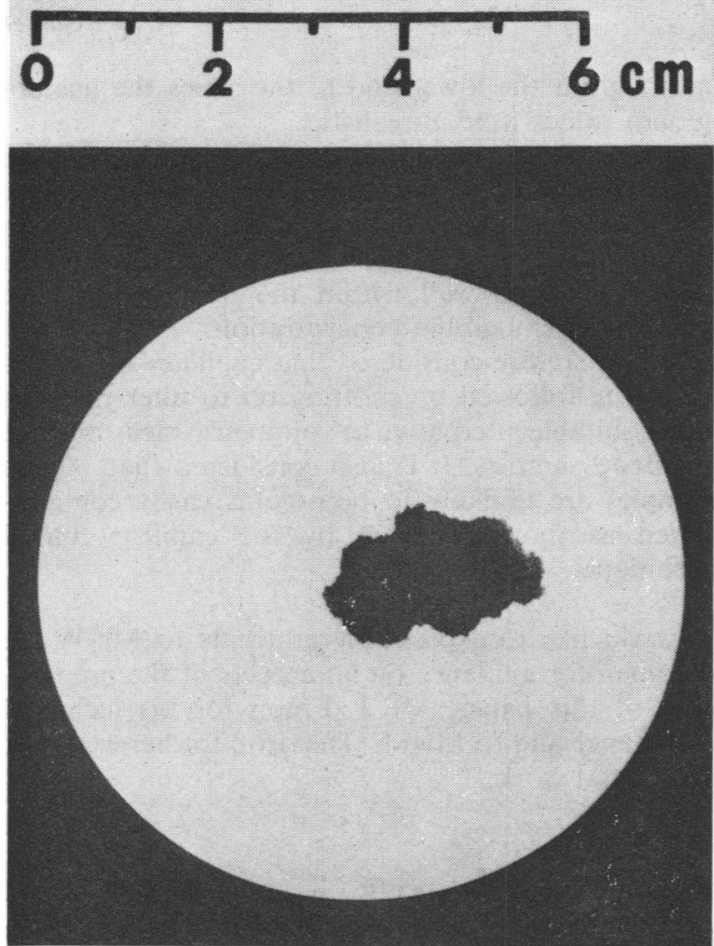

Fig. $350 \mu l$ of blood, haemoglobin concentration $16.5 \mathrm{~g} / \mathrm{dl}$, spotted on to Whatman No. 4 filter paper.
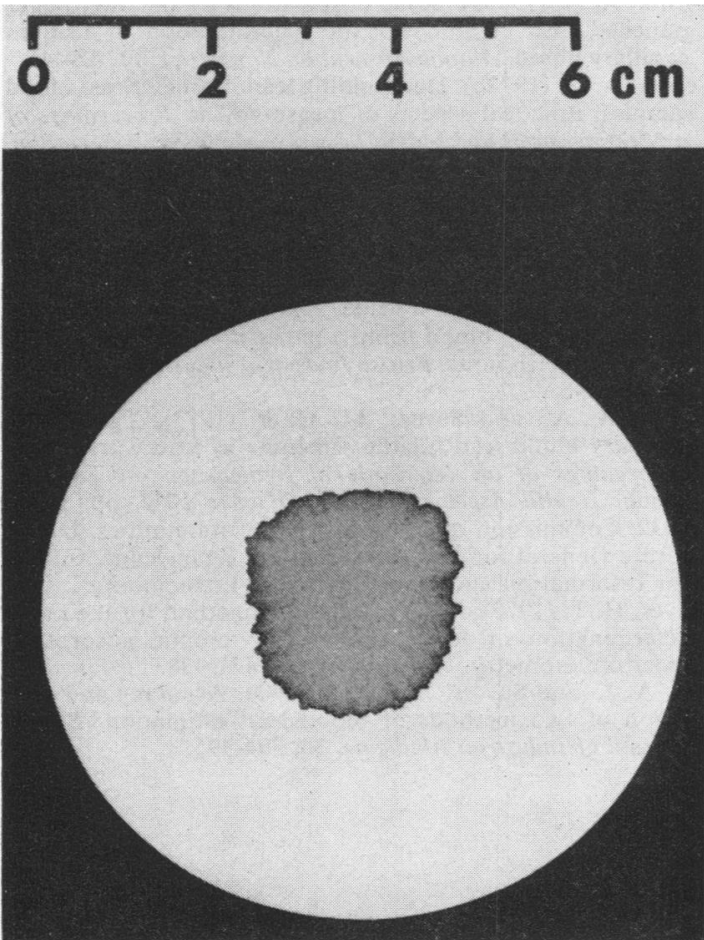

Fig. $550 \mu l$ of blood, haemoglobin concentration $4.5 \mathrm{~g} / \mathrm{dl}$, spotted on to Whatman No. 4 filter paper.
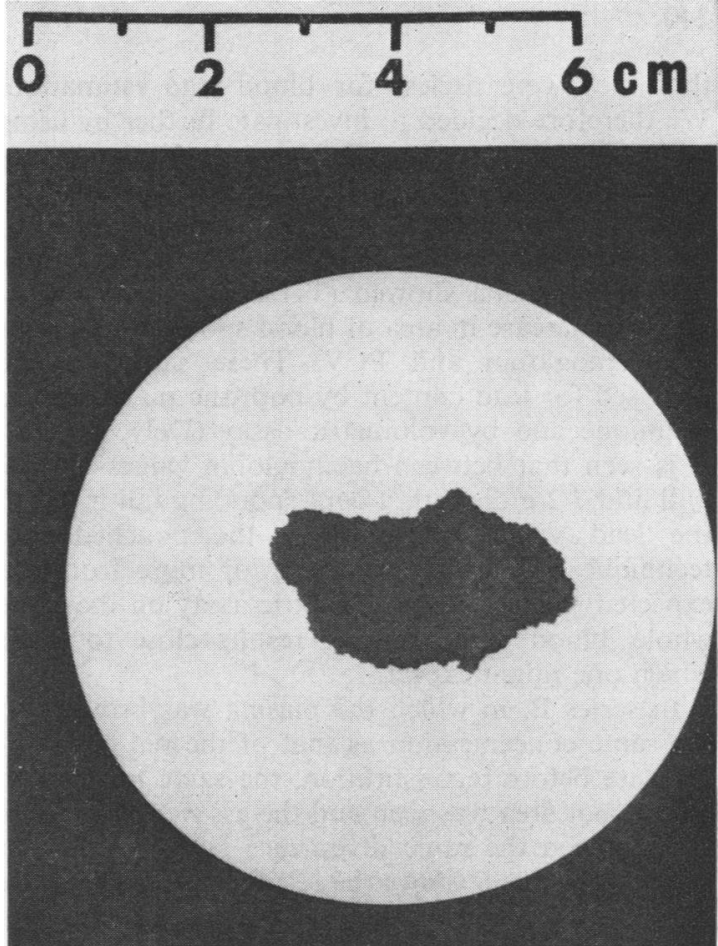

Fig. $4100 \mu$ l of blood, haemoglobin concentration $16.5 \mathrm{~g} / \mathrm{dl}$, spotted on to Whatman No. 4 filter paper.
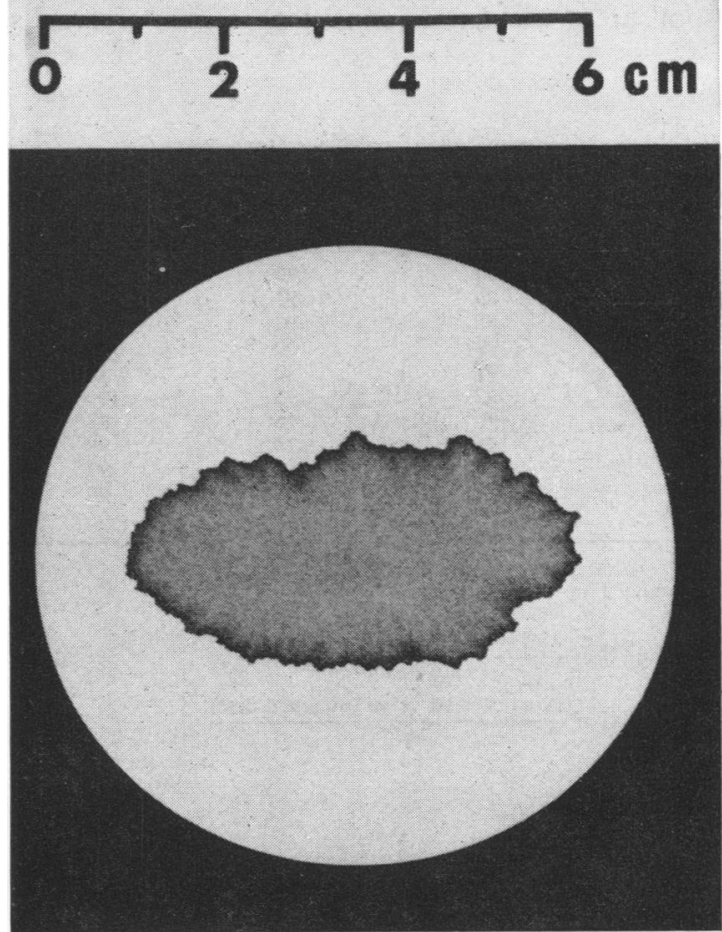

Fig. $6100 \mu$ l of blood, haemoglobin concentration $4.5 \mathrm{~g} / \mathrm{dl}$, spotted on to Whatman No. 4 filter paper. 
that they were useless for blood lead estimation. We therefore decided to investigate further by using laboratory-prepared samples in which all the factors under consideration could be more closely controlled.

The artificial series $\mathbf{A}$ in which lead was added to the red cell concentrate before volumetric reconstitution with plasma showed (Table 3) a similar progressive increase in area of blood spot with decrease in haemoglobin and PCV. These samples were analysed for lead content by both the punched disc technique and by volumetric assay (Delves, 1970). It is seen that between haemoglobin values of 14.9 $\mathrm{g} / \mathrm{dl}$ and $7 \cdot 2 \mathrm{~g} / \mathrm{dl}$, with a corresponding fall in PCV, the lead value estimated by the punched disc technique may deviate by $50 \%$ or more from the expected values. The volumetric assay on the same whole blood samples gave results close to those which one might expect.

In series $\mathbf{B}$, in which the plasma was brought to the same concentration as that of the red cell concentrate before reconstitution, the same increase in blood spot area was seen and the assayed lead levels also showed the same divergence between the two methods. Table 6 shows the results of correcting the blood lead levels from the punched disc experiments for haemoglobin ratios, for PCV ratios and for relative areas taking the prime sample $\mathrm{B} 10$ as reference. Only the corrections for relative blood spot areas yielded a consistent series of results,

Table 6 Comparison of results after correction

\begin{tabular}{lccc}
\hline Sample no. & $\begin{array}{l}\text { Column I } \\
(P C V)\end{array}$ & $\begin{array}{l}\text { Column II } \\
(\mathrm{Hb})\end{array}$ & $\begin{array}{l}\text { Column III } \\
(\text { area })\end{array}$ \\
\hline B10 & 100 & 100 & 100 \\
B9 & 89 & 91 & 97 \\
B8 & 89 & 91 & 95 \\
B7 & 99 & 100 & 124 \\
B6 & 91 & 92 & 112 \\
B5 & 92 & 95 & 100 \\
B4 & 96 & 96 & 93 \\
B3 & 121 & 125 & 98 \\
B2 & 167 & 170 & 97 \\
B1 & 294 & 301 & 98 \\
B0 & 1110 & 1560 & 96 \\
\hline
\end{tabular}

Column $\quad I=\frac{53.8 \times \text { lead value (punched disc) }}{\text { PCV (sample) }}$

Column II $=\frac{18.9 \times \text { lead value (punched disc) }}{\text { Hb (sample) }}$

Column III $=\frac{\text { Area } \times \text { lead value (punched disc) }}{365}$ although at the lower end of the series the haemoglobin values were unrealistic.

Using the punched disc technique, unless the result obtained is corrected with reference to the spread of the standard blood used, the result may deviate considerably from the true value. This deviation starts well within the normal reference range of haemoglobin concentration.

It is therefore considered that capillary or venous sampling followed by spotting on to filter paper is not a suitable alternative to volumetric measurement of blood samples. It is also considered that venous samples are unlikely to become as easily contaminated as those obtained by the capillary blood technique.

I would like to express my gratitude to $\mathrm{Mr} \mathrm{W}$. B. Yeoman for guidance on all aspects of the preparation of this paper, Mr J. Epton for his technical assisitance and to Miss E. Harrison for her excellent secretarial work.

\section{References}

Ainsworth, M., Davies, D. R., and Eveleigh, J. W. (1953). The spread and distribution of blood drops on filter paper. Porton Technical Paper No. 351.

CEMA Note of Guidance (1972). I/MS/468/194/71. HMSO: London.

Cernik, A. A. (1973a). Some observations on the filter paper punched disc method for the determination of lead in capillary blood. Atomic Absorption Newsletter, 12, 42-44.

Cernik, A. A. (1973b). Determining lead in small dried blood samples. Practical aspects of measurement. Proceedings of a Meeting organised by the Lead Development Association, pp. 26-28. Lead Development Association, 34 Berkeley Square, London.

Cernik, A. A. (1974). Determination of blood lead using a 4.0 mm paper punched disc carbon sampling cup technique. British Journal of Industrial Medicine, 31, 239-244.

Cernik, A. A., and Sayers, M. H. P. (1971). Determination of lead in capillary blood using a paper punched disc atomic absorption technique. British Journal of Industrial Medicine, 28, 392-398.

Cernik, A. A., and Sayers, M. H. P. (1973). The use of capillary blood lead for the screening of lead workers. In Proceedings of an International Symposium on Environmental Health Aspects of Lead, October 1972, pp. 10231032. Commission of the European Communities, Directorate General for Dissemination of Knowledge, Centre for Information and Documentation, Luxembourg.

Delves, H. T. (1970). A micro-sampling method for the rapid determination of lead in blood by atomic absorption spectrophotometry. The Analyst, 95, 431-438.

Fox, A. J., and Sayers, M. H. P. (1973). Accuracy and precision of two methods of blood lead estimation. British Journal of Industrial Medicine, 30, 394-395. 